\title{
UPAYA MENINGKATKAN HUBUNGAN SOSIAL ANTAR TEMAN SEBAYA MELALUI LAYANAN BIMBINGAN KELOMPOK PADA SISWA KELAS VII B SMPN 1 BANYUGLUGUR KABUPATEN SITUBONDO TAHUN AJARAN 2018/2019
}

\author{
Abd.Rahman ${ }^{1}$ \\ ${ }^{1}$ SMP Negeri 1 Banyuglugur \\ Correspondence Email: rahman_abd11@gmail.com
}

Received: Feb 15, $2021 \quad$ Revised: Feb 18, $2021 \quad$ Accepted: Feb 24, 2021

\begin{abstract}
ABSTRAK
Tujuan penelitian ini untuk mengetahui 1) Hubungan sosial antar teman sebaya sebelum diberikan layanan bimbingan kelompok pada siswa kelas VII B SMPN 1 Banyuglugur Kabupaten Situbondo tahun ajaran 2018/2019,2) Hubungan sosial antar teman sebaya setelah diberikan layanan bimbingan kelompok pada siswa kelas VII B SMPN 1 Banyuglugur Kabupaten Situbondo tahun ajaran 2018/2019, dan 3) Adakah peningkatan hubungan sosial antar teman sebaya setelah diberikan layanan bimbigan kelompok pada siswa kelas VII B SMPN 1 Banyuglugur Kabupaten Situbondo tahun ajaran 2018/2019. Jenis penelitian yang digunakan adalah penelitian eksperimen (eksperimental). Populasi dalam penelitian ini adalah siswa kelas VII B SMPN 1 Banyuglugur. Teknik pengambilan sampel yang digunakan dalam penelitian ini adalah purposive sampling (sampling bertujuan). Sampel dalam penelitian ini adalah siswa yang mencerminkan tingkat hubungan sosial antar teman sebayanya rendah dibandingkan siswa yang lain. Metode pengumpulan data dalam penelitian ini dengan menggunakan skala psikologi dengan jumlah 52 item yang sebelumnya telah diuji cobakan sehingga dapat digunakan dalam penelitian. Sedangkan metode analisis data untuk mengetahui peningkatan hubungan sosial antar teman sebaya melalui layanan bimbingan kelompok adalah menggunakan uji statistik wilcoxon. Sebelum memperoleh layanan bimbingan kelompok, tingkat hubungan sosial antar teman sebaya siswa termasuk dalam kategori rendah dengan persentase skor rata-rata 51,23\% dengan kriteria rendah. Sedangkan setelah memperoleh layanan bimbingan kelompok, hubungan sosial antar teman sebaya memperoleh skor rata-rata 68,50\% dengan kriteria tinggi. Dari uji wilcoxon diperoleh $\mathrm{Z}_{\text {hitung }}$ sebesar 2,803 dan nilai $Z_{\text {tabel }}$ pada taraf signifikan 5\% dan $\mathrm{N}=10$ diperoleh $\mathrm{Z}_{\text {tabel }}$ sebesar 1,96. Dengan demikian dapat disimpulkan bahwa layanan bimbingan kelompok dapat meningkatkan hubungan sosial antar teman sebaya siswa kelas VII B SMPN 1 Banyuglugur.
\end{abstract}

Kata kunci: hubungan sosial antar teman sebaya, layanan bimbingan kelompok

\section{PENDAHULUAN}

Manusia terlibat dalam situasi sosial, dimana terdapat hubungan antara manusia yang satu dengan manusia yang lain yang dapat saling mempengaruhi. Hubungan sosial dimulai dari tingkat yang sederhana yang didasari oleh kebutuhan yang sederhana. Semakin dewasa, kebutuhan manusia menjadi kompleks, dan dengan demikian tingkat hubungan sosial juga berkembang menjadi sangat kompleks. Pada jenjang perkembangan remaja, seorang remaja 
bukan saja memerlukan orang lain demi memenuhi kebutuhan pribadinya, tetapi untuk berpartisipasi dan berkontribusi memajukan kehidupan masyarakatnya.

Remaja sebagai manusia yang sedang tumbuh dan berkembang terus melakukan interaksi sosial baik antara remaja maupun terhadap lingkungan lain. Salah satu tugas dari perkembangan masa remaja yang tersulit adalah hubungan dengan penyesuaian sosial (Hurlock, 1997: 213), remaja harus menyesuaiakan diri dengan lawan jenis dalam hubungan yang sebelumnya belum pernah ada dan harus menyesuaiakan dengan orang dewasa diluar lingkungan keluarga dan sekolah.

Berdasarkan teori yang dikemukakan oleh Ali dan Asrori dapat disimpulkan bahwa karakteristik perkembangan sosial remaja timbul karena: (1) berkembangnya kesadaran akan kesunyian dan dorongan akan pergaulan, (2) adanya upaya-upaya memilih nilai-nilai sosial, (3) meningkatnya ketertarikan pada lawan jenis, (4) mulai cenderungan memilih karier tertentu. Karakteristik perkembangan sosial diatas kaitannya dengan penelitian adalah sebagai bahan referensi peneliti untuk meningkatkan hubungan sosial siswa.

Menurut Alisyahbana dalam Ali dan Asroi (2005: 85) hubungan sosial diartikan sebagai cara-cara individu bereaksi terhadap orang-orang disekitarnya dan bagaimana pengaruh hubungan itu terhadap dirinya, termasuk juga penyesuaian diri terhadap lingkungan seperti makan dan minum sendiri, berpakaian sendiri, bagaimana mentaati peraturanperaturan dan perjanjian-perjanjian dalam kelompok atau organisasi, dan sebagainya. Menurut Hurlock (1997:13) untuk mencapai tujuan dari pola sosialisasi dewasa, remaja harus banyak membuat penyesuaian baru yang terpenting dan tersulit adalah penyesuaian diri dengan meningkatnya pengaruh kelompok teman sebaya, perubahan dalam perilaku sosial, pengelompokan sosial yang baru, nilai-nilai baru dalam seleksi pemimpin.

Berdasarkan kenyataan di lapangan yang diperoleh dari hasil observasi awal pada hari Selasa, 17 September 2018 dapat diperoleh informasi bahwa di SMPN 1 Banyuglugur terdapat siswa-siswa yang dapat menjalin hubungan sosial dengan baik dan ada siswa yang kurang dapat menjalin hubungan sosial dengan baik, gejala yang muncul antara lain siswa kurang dapat menunjukan komunikasi antar pribadi yang baik, sehingga menyebabkan komunikasi yang kurang efektif, baik komunikasi verbal maupun non verbal, misalnya mudah cemas, mudah gugup, ketika berkomunikasi tidak memperhatikan kontak mata dengan lawan komunikasi, lebih pendiam, selain itu siswa yang kurang dapat menjalin hubungan sosial dengan baik mengalami kesulitan untuk menyesuaikan diri dengan teman dan lingkungan sekitarnya, sehingga menyebabkan kurangnya kerjasama siswa dilingkungan sekolah.

Kesulitan yang dialami siswa dalam menjalin hubungan sosial dengan teman sebayanya dapat menimbulkan masalah dalam mengembangkan potensi yang dimilikinya 
sehingga dapat mempengaruhi prestasinya disekolah. Melihat masa remaja yang sangat potensial dan dapat berkembang kearah positif maupun negatif maka intervensi edukatif dalam bentuk pendidikan, bimbingan maupun pendampingan sangat diperlukan untuk mengarah perkembangan potensi remaja tersebut agar berkembang ke arah positif dan produktif.

Layanan bimbingan dan konseling di sekolah bertujuan untuk membantu individu mengembangkan diri secara optimal sesuai dengan tahap perkembangan dan predisposisi yang dimiliknya (seperti kemampuan dasar dan bakat-bakatnya), berbagai latar belakang yang ada serta sesuai dengan tuntutan positif linkungannya. Menurut Prayitno (1995: 2) menyatakan bahwa layanan bimbingan kelompok merupakan salah satu layanan bimbingan dan konseling yang bertujuan untuk mengembangkan kemampuan sosialisasi siswa, khususnya kemampuan komunikasi peserta layanan yang di berikan oleh konselor sekolah untuk membantu individu menjadi insan yang berguna dalam kehidupannya yang memiliki berbagai wawasan, pandangan, interpretasi, pilihan, penyesuaian dan ketrampilan yang tepat berkenaan dengan diri sendiri dan linkungannya.

Kemampuan bersosialisai/ berkomunikasi seseorang sering terganggu oleh perasaan, pikiran, persepsi, wawasan dan sikap yang tidak obyektif, sempit, dan terkungkung serta tidak efektif, maka dengan adanya kegiatan bimbingan kelompok diharapkan mampu memberikan bantuan kepada individu agar dapat mengatur kegiatan-kegiatan hidup, mengembangkan sudut pandangnya, mengambil keputusannya sendiri dan menanggung bebannya sendiri serta dapat mengembangkan perkembangan sosial secara maksimal.

Fungsi bimbingan kelompok adalah sebagai media pemberian bantuan kepada individu dalam suasana kelompok melalui informasi-informasi yang disajikan di dalamnya. Menurut Prayitno (2001:87-88) menjelaskan tujuan dan fungsi bimbingan kelompok di maksudkan untuk memungkinkan siswa secara bersama-bersama memperoleh bahan dari nara sumber yang bermanfaat bagi kehidupan sehari-hari baik sebagai individu maupun sebagai pelajar, anggota keluarga, dan masyarakat. Sedangkan romalah (2001: 3-4) menyatakan bahwa bimbingan kelompok ditujukan untuk mencegah timbulnya masalah pada individu dan mengembangkan potensi siswa.

Layanan bimbingan kelompok dijadikan pilihan layanan untuk meningkatkan hubungan sosial siswa terhadap teman sebaya karena layanan bimbingan kelompok merupakan proses pemberian bantuan dalam situasi kelompok dari konselor kepada klien dengan memanfaatkan dinamika kelompok untuk mencapai tujuan yaitu perubahan pada diri klien baik itu dalam bentuk pandangan, sikap, sifat, maupun keterampilan yang lebih memungkinkan siswa untuk mewujudkan diri secara lebih optimal dengan tetap 
memperhatikan potensi yang dimilikinya. Pada pelaksanaan bimbingan kelompok, dinamika kelompok sengaja ditumbuh kembangkan karena dinamika kelompok adalah hubungan interpersonal yang ditandai dengan semangat kerjasama antar anggota kelompok, saling berbagi pengetahuan, pengalaman dan mencapai tujuan kelompok, sehingga melalui dinamika kelompok kemampuan berkomunikasi, dan bersosialisasi dengan teman sebaya dapat ditingkatkan.

\section{METODOLOGI PENELITIAN}

\section{A. JenisPenelitian}

Jenis penelitian dalam penelitian ini adalah penelitian eksperimen. Adapun langkah-langkah yang akan ditempuh dalam pelaksanaan eksperimen penelitian ini meliputi:

\section{Pre Test}

Pre-test dilakukan dengan menggunakan instrument berupa skala Psikologi hubungan sosial.

\section{Treatment/ Perlakuan}

Perlakuan (treatment) yang diberikan adalah berupa bimbingan kelompok. Treatment diberikan sebanyak 8 kali dengan durasi waktu 45 menit untuk setiap kali pertemuan.

\begin{tabular}{|c|c|c|c|c|}
\hline No & Pert. & Indikator kreativitas & Topik Tugas & Waktu \\
\hline 1 & $\mathrm{I}$ & Memiliki sahabat dekat & $\begin{array}{l}\text { Persahabatan } \\
\text { Pengertian sahabat } \\
\text { Faktor-faktor penghancur hubungan } \\
\text { persahabatan } \\
\text { Cara-cara menjaga keharmonisan } \\
\text { hubungan persahabatan }\end{array}$ & 45 Menit \\
\hline 2 & II & Keterampilan sosial & $\begin{array}{l}\text { Cara-cara bergaul yang baik } \\
\text { Faktor-fator penyebab perselisihan } \\
\text { Dampak negatif perselisihan } \\
\text { Cara-cara menjalin hubungan baik } \\
\text { Dampak positif hubungan baik antar } \\
\text { teman sebaya }\end{array}$ & 45 Menit \\
\hline 3 & III & Interaksi sosial & $\begin{array}{l}\text { Kerjasama Kelompok } \\
\text { Bentuk-bentuk kerjasama kelompok } \\
\text { Hal-hal yang harus dilakukan ketika } \\
\text { bekerjasama } \\
\text { Tujuan dan manfaat kerjasama }\end{array}$ & 45 Menit \\
\hline 4 & IV & Keterampilan sosial & $\begin{array}{l}\text { Mengatasi konflik antar pribadi } \\
\text { Contoh-contoh konflik } \\
\text { Dampak terjadinya konflik } \\
\text { Cara mengatasi konflik }\end{array}$ & 45 Menit \\
\hline 5 & $\mathrm{~V}$ & Penyesuaian sosial & $\begin{array}{l}\text { Penyesuaian diri } \\
\text { Pengertian penyesuaian diri } \\
\text { Dampak positif penyesuaian diri } \\
\text { yang baik }\end{array}$ & 45 Menit \\
\hline
\end{tabular}




\begin{tabular}{|l|l|l|l|l|}
\hline & & & $\begin{array}{l}\text { Cara-cara mengembangkan } \\
\text { kemampuan penyesuaian diri yang } \\
\text { baik }\end{array}$ & \\
\hline 6 & VI & $\begin{array}{l}\text { Dipercaya oleh teman } \\
\text { sebaya dalam posisi } \\
\text { tanggung jawab tertentu }\end{array}$ & $\begin{array}{l}\text { Menjadi pribadi yang baik dan } \\
\text { bertanggung jawab } \\
\text { Pengertian pribadi yang baik dan } \\
\text { bertanggung jawab } \\
\text { Faktor-faktor penyebab sulitnya } \\
\text { bertanggung jawab } \\
\text { Langkah-langkah menjadi pribadi } \\
\text { yang baik dan bertanggung jawab }\end{array}$ & 45 Menit \\
\hline 7 & VII & Interaksi sosial & $\begin{array}{l}\text { Befikir positif } \\
\text { Pengertian berfikir positif } \\
\text { Ciri-ciri berfikir positif } \\
\text { Manfaat berfikir positif }\end{array}$ & 45 Menit \\
\hline 8 & VIII & Interaksi sosial & $\begin{array}{l}\text { Perbedaan kelompok atau genk } \\
\text { Pengertian perbedaan kelompok atau } \\
\text { genk } \\
\text { Dampak adanya genk } \\
\text { Cara-cara menghindari terjadinya } \\
\text { dampak negatif dari genk }\end{array}$ & 45 Menit \\
& & &
\end{tabular}

\section{Post Test}

Post test adalah hasil perlakuan dengan menggunakan skala psikologi hubungan sosial kepada sampel penelitian sesudah diberi perlakuan.

\section{Analisis Data}

Proses analisis data yaitu menganalisis data yang sudah terkumpul dengan menggunakan perhitungan uji wilcoxon. Alasan menggunakan analisis uji wilcoxon karena data dalam penelitian bentuknya ordinal atau berjenjang (Sugiyono, 2007: 45).

\section{B. Variabel Penelitian}

a. Variabel bebas (independen) merupakan variabel yang diukur pengaruhnya atau variabel yang mempengaruhi variabel lain, yaitu layanan bimbingan kelompon (X).

b. Variabel bergantung (dependen) yaitu variabel yang merupakan akibat adanya variabel bebas, yaitu hubungan sosial antar teman sebaya (Y).

\section{Instrumen Penelitian}

Instrumen yang digunakan dalam penelitian ini berupa skala hubungan sosial antar teman sebaya. Dengan menggunakan instrumen ini dapat diketahui tingkat hubungan sosial antar teman sebaya pada siswa kelas VII B SMPN 1 Banyuglugur. Skala ini dimaksudkan untuk memperoleh data penjaringan sampel, pre test dan post test.

Data yang diperoleh dari hasil analisis skala hubungan sosial antar teman sebaya ini bersifat kualitatif. Oleh karena itu agar data tersebut dapat dianalisis secara kuantitatif, 
maka jawaban yang diberikan oleh responden diberi skor berdasarkan skala interval dengan metode skala likert.

Adapun Langkah-langkah yang ditempuh dalam penyusunan instrumen dilakukan dalam beberapa tahap, baik dalam pembuatan maupun uji coba. Untuk lebih jelasnya dapat dilihat seperti berikut:

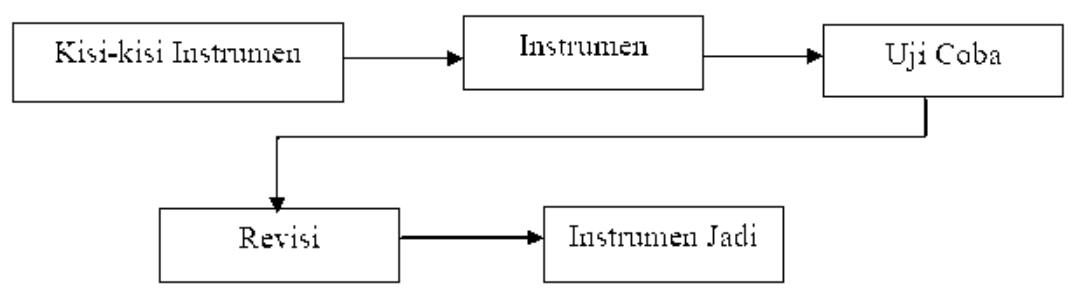

\section{HASIL PENELITIAN DAN PEMBAHASAN}

\section{Hasil Analisis Deskriptif Kuantitatif}

Gambaran tingkat hubungan sosial antar teman sebaya siswa per indikator sebelum mendapatkan layanan bimbingan kelompok dapat dilihat pada tabel di bawah ini:

\begin{tabular}{|c|l|c|c|}
\hline No & \multicolumn{1}{|c|}{ Indikator } & \% & Kriteria \\
\hline 1. & Memiliki sahabat dekat & 53,60 & SD \\
\hline 2. & $\begin{array}{l}\text { Dipercaya oleh teman sebaya dalam } \\
\text { posisi tanggung jawab tertentu }\end{array}$ & 29,50 & SR \\
\hline 3. & Penyesuaian sosial & 56,55 & SD \\
\hline 4. & Interaksi sosial & 51,47 & $\mathrm{R}$ \\
\hline 5. & Keterampilan sosial & 51,33 & $\mathrm{R}$ \\
\hline \multicolumn{2}{|c|}{ Rata-rata } & 48,49 & $\mathrm{R}$ \\
\hline
\end{tabular}

Pada tabel diatas menjelaskan tentang gambaran tingkat pencapaian hubungan sosial antar teman sebaya siswa sebelum mendapatkan perlakuan yaitu layanan bimbingan kelompok per indikator, dari rata-rata seluruh indikator berada pada kategori rendah dengan rata-rata $48,49 \%$. Hal ini jelas membuktikan bahwa kemampuan hubungan sosial antar teman sebaya siswa masih perlu untuk ditingkatkan.

Gambaran tingkat hubungan sosial antar teman sebaya siswa per indikator setelah mendapatkan layanan bimbingan kelompok.

\begin{tabular}{|c|l|c|c|}
\hline Yo & \multicolumn{1}{|c|}{ Indikator } & $\%$ & Kriteria \\
\hline 1. & Memiliki sahabat dekat & 65,60 & SD \\
\hline 2. & $\begin{array}{l}\text { Dipercaya oleh teman sebaya dalam } \\
\text { posisi tanggung jawab tertentu }\end{array}$ & 65,50 & SD \\
\hline 3. & Penyesuaian sosial & 69,27 & $\mathrm{~T}$ \\
\hline 4. & Interaksi sosial & 67,73 & SD \\
\hline 5. & Keterampilan sosial & 72,67 & $\mathrm{~T}$ \\
\hline \multicolumn{2}{|c|}{ Rata-rata } & 68,50 & $\mathrm{~T}$ \\
\hline
\end{tabular}


Pada tabel diatas menjelaskan tentang gambaran tingkat pencapaian hubungan sosial antar teman sebaya siswa setelah mendapatkan perlakuan yaitu layanan bimbingan kelompok per indikator, dari rata-rata seluruh indikator berada pada kategori tinggi dengan rata-rata 68,50 kategori sedang,

Terjadi peningkatan hubungan sosial antar teman sebaya setelah mendapatkan treatment. Adapun peningkatan tingkat hubungan sosial antar teman sebaya setelah diberikan layanan bimbingan kelompok pada siswa VII B SMPN 1 Banyuglugur, seperti tabel berikut ini:

\begin{tabular}{|c|c|c|c|c|c|c|c|c|}
\hline \multirow{2}{*}{ Resp } & \multicolumn{3}{|c|}{ Pre-Test } & \multicolumn{3}{c|}{ Post-test } & \multicolumn{2}{c|}{ Peningkatan } \\
\cline { 2 - 9 } & $\Sigma$ & $\%$ & K & $\Sigma$ & $\%$ & K & Skor & $\%$ \\
\hline DH & 134 & 51,54 & R & 167 & 64.23 & SD & 33 & 12,78 \\
\hline FZ & 129 & 49,62 & R & 187 & 71,92 & T & 58 & 22,3 \\
\hline MF & 135 & 51,92 & R & 202 & 77,69 & T & 67 & 25,77 \\
\hline SF & 133 & 51,15 & R & 172 & 66,15 & SD & 39 & 15 \\
\hline AS & 131 & 50,38 & R & 181 & 69,62 & T & 50 & 19,24 \\
\hline IL & 133 & 51.15 & R & 176 & 67.69 & SD & 43 & 16,54 \\
\hline KU & 135 & 51,92 & R & 175 & 67.31 & SD & 40 & 15,39 \\
\hline AD & 134 & 51,54 & R & 183 & 70,38 & T & 49 & 18,84 \\
\hline AA & 135 & 51,92 & R & 163 & 62.69 & SD & 28 & 10,77 \\
\hline TM & 132 & 50.77 & R & 175 & 67.31 & SD & 43 & 16.54 \\
\hline Rata-1ata & $\mathbf{1 3 3}$ & $\mathbf{5 1 , 2 3}$ & R & $\mathbf{1 7}$ & 68,50 & T & $\mathbf{4 5}$ & 17,27 \\
\hline
\end{tabular}

Berdasarkan tabel diatas diperoleh penigkatan tingkat hubungan sosial antar teman sebaya rata-rata $17,27 \%$, dengan demikian menunjukkan bahwa pemberian layanan bimbingan kelompok pada siswa kelas VII B SMPN 1 Banyuglugur membawa dampak yang positif bagi hubungan sosial antar teman sebaya.

Hal lain yang dapat dibuktikan untuk mengetahui apakah hubungan sosial antar teman sebaya benar-benar bisa di tingkatkan melalui layanan bimbingan kelompok yaitu dengan menggunakan analisis statistik non parametrik yaitu Uji Wilcoxon. Hasil uji Wilcoxon adalah sebagai berikut.

\begin{tabular}{|c|c|c|c|c|c|c|c|}
\hline \multirow[b]{2}{*}{ Yo } & \multirow{2}{*}{ Nama } & \multirow{2}{*}{$\begin{array}{l}\text { Pre-test } \\
\text { (X 1) }\end{array}$} & \multirow{2}{*}{$\begin{array}{l}\text { Post-1est } \\
\text { (X2) }\end{array}$} & \multirow{2}{*}{$\begin{array}{c}\text { Beda } \\
\text { (X2-X1) }\end{array}$} & \multicolumn{3}{|c|}{ Tanda jenjang } \\
\hline & & & & & Jenjang & + & - \\
\hline 1. & $\mathrm{DH}$ & 51 & 64 & -13 & 2 & 2 & 0.0 \\
\hline 2. & FZ & 50 & 72 & -22 & 9 & 9 & 0.0 \\
\hline 3. & MF & 52 & 78 & -26 & 10 & 10 & 0.0 \\
\hline 4. & $\mathrm{SF}$ & 51 & 66 & -15 & 3.5 & 3.5 & 0.0 \\
\hline 5. & AS & 50 & 70 & -20 & 8 & 8 & 0.0 \\
\hline 6. & IL & 51 & 68 & -17 & 6 & 6 & 0.0 \\
\hline 7. & $\mathrm{KU}$ & 52 & 67 & -15 & 3.5 & 3.5 & 0.0 \\
\hline 8. & $\mathrm{AD}$ & 52 & 70 & -18 & 7 & 7 & 0.0 \\
\hline 9. & $\mathrm{AA}$ & 52 & 63 & -11 & 1 & 1 & 0.0 \\
\hline 10. & $\mathrm{TM}$ & 51 & 67 & -16 & 5 & 5 & 0.0 \\
\hline & & & Juml: & & & 55 & 0,0 \\
\hline
\end{tabular}


Dari hasil perhitungan dengan menggunakan analisis uji wilcoxon diperoleh Zhitung = 2,803 dan Ztabel $=1,96$ sehingga Zhitung $>$ Ztabel. Dengan demikian maka Ha diterima dan Ho ditolak. Hasil tersebut menunjukkan tingkat hubungan sosial antar teman sebaya siswa meningkat setelah memperoleh layanan bimbingan kelompok. Dengan kata lain hubungan sosial antar teman sebaya siswa dapat ditingkatkan melalui pemberian layanan bimbingan kelompok

\section{Hasil Analisis Deskriptif Kualitatif}

Hasil analisis deskriptif kualitatif merupakan uraian mengenai hasil penelitian yang berdasarkan kepada hasil analisis dari pengamatan peneliti pada saat pelaksanaan kegiatan layanan bimbingan kelompok. Selain analisis pengamatan proses pelaksanaan layanan bimbingan kelompok, terdapat pula uraian mengenai evaluasi pemahaman diri dan tindakan (UCA) anggota kelompok setelah pelaksanaan bimbingan kelompok. Evaluasi UCA tersebut dilakukan melalui tanya jawab antara pemimpin kelompok dengan semua anggota kelompok mengenai pemahaman baru yang diperoleh dari kegiatan bimbingan kelompok, perasaan selama mengikuti kegiatan bimbingan kelompok, dan komitmen mengenai tindakan yang akan dilakukan setelah mengikuti kegiatan bimbingan kelompok.

Uraian pelaksanaan layanan bimbingan kelompok pada tiap tahap pelaksanaan adalah sebagai berikut:

1) Tahap Pembentukan

Pada tahap pembentukan dinjelaskan pengertian, tujuan, cara pelaksanaan layanan bimbingan kelompok serta asas-asas yang harus dipatuhi dalam kegiatan bimbingan kelompok.

2) Tahap peralihan

Pada tahap peralihan praktikan mengalihkan kegiatan awal kelompok ke kegiatan berikutnya yang lebih terarah dalam pencapaian tujuan kelompok. Praktikan menjelaskan kembali secara singkat mengenai cara pelaksanaan bimbingan kelompok dan mengharapkan semua anggota kelompok dapat aktif dan terbuka dalam mengemukakan pendapatnya.

3) Tahap kegiatan

Pada tahap Kegiatan praktikan memberikan penjelasan mengenai topik yang akan dibahas hal ini bertujuan agar anggota kelompok mempunyai gambaran tentang topik yang akan dibahas. Praktikan mengawali pembahasan topik dengan menanyakan arti sahabat menurut masing-masing anggota. Pada awal pertemuan ini anggota kelompok masih nampak canggung dan malu untuk mengungkapkan pendapatnya, anggota kelompok mengeluarkan pendapatnya setelah ditunjuk oleh praktikan namun praktikan memberikan dorongan agar 
anggota kelompok yang lain mau mengunkapkan pendapatnya tanpa harus ditunjuk oleh praktikan.

4) Tahap pengakhiran

Pada tahap ini praktikan mengungkapkan bahwa kegiatan akan diakhiri dan menyimpulkan hasil topik yang telah dibahas, kemudian praktikan menanyakan kepada anggota kelompok tentang kesan-kesan, pesan, dan perasaan anggota kelompok setelah mengikuti kegiatan bimbingan kelompok

Pelaksanaan bimbingan kelompok dilakukan selama 8 kali pertemuan. Pertemuan pertama sampai pertemuan delapan terjadi peningkatan masing- masing indikator hubungan sosial antar teman sebaya yang meliputi:

\section{Memiliki sahabat dekat}

Berdasarkan pengamatan selama proses pelaksanaan layanan bimbingan kelompok pada pertemuan pertama, indikator memiliki sahabat dekat ini sudah mulai muncul, begitu juga pada pertemuan-pertemuan selanjutnya. Berdasarkan hasil pengamatan, hasil perhitungan pre-test dan post-test, juga hasil analisis wilcoxon dapat disimpulkan bahwa sampai akhir pertemuan kedelapan indikator hubungan sosial antar teman sebaya siswa tentang memiliki sahabat dekat mengalami peningkatan

\section{Dipercaya oleh teman sebaya dalam posisi tanggung jawab tertentu}

Dari hasil analisis deskriptif kondisi akhir dipercaya oleh teman sebaya dalam posisi tanggung jawab tertentu ini juga mengalami peningkatan yaitu dari kategori sangat rendah meningkat menjadi kategori sedang. Hal ini membuktikan bahwa adanya peningkatan hubungan sosial antar teman sebaya siswa melalui layanan bimbingan kelompok. Berdasarkan hasil pengamatan, hasil perhitungan pre-test dan post-test, juga hasil analisis wilcoxon dapat disimpulkan bahwa sampai akhir pertemuan kedelapan indikator hubungan sosial antar teman sebaya siswa tentang dipercaya oleh teman sebaya dalam posisi tanggung jawab tertentu mengalami peningkatan

\section{Memiliki penyesuaian sosial yang baik}

Dari hasil analisis deskriptif kondisi akhir kemampuan memiliki penyesuaian sosial yang baik ini juga mengalami peningkatan yaitu dari kategori sedang meningkat menjadi kategori tinggi. Hal ini membuktikan bahwa adanya peningkatan hubungan sosial antar teman sebaya siswa melalui layanan bimbingan kelompok

Berdasarkan hasil pengamatan, hasil perhitungan pre-test dan post-test, juga hasil analisis wilcoxon dapat disimpulkan bahwa sampai akhir pertemuan kedelapan indikator hubungan sosial antar teman sebaya siswa tentang memiliki penyesuaian sosial yang baik mengalami peningkatan 


\section{Berinteraksi dengan teman sebaya}

Dari hasil analisis deskriptif kondisi akhir kemampuan berinteraksi dengan teman sebaya ini juga mengalami peningkatan yaitu dari kategori rendah meningkat menjadi kategori sedang. Hal ini membuktikan bahwa adanya peningkatan hubungan sosial antar teman sebaya siswa melalui layanan bimbingan kelompok.

Berdasarkan hasil pengamatan, hasil perhitungan pre-test dan post-test, juga hasil analisis wilcoxon dapat disimpulkan bahwa sampai akhir pertemuan kedelapan indikator hubungan sosial antar teman sebaya siswa tentang berinteraksi dengan teman sebaya mengalami peningkatan

\section{Memiliki keterampilan sosial yang baik}

Dari hasil analisis deskriptif kondisi akhir kemampuan memiliki keterampilan sosial yang baik ini juga mengalami peningkatan yaitu dari kategori rendah meningkat menjadi kategori tinggi. Hal ini membuktikan bahwa adanya peningkatan hubungan sosial antar teman sebaya siswa melalui layanan bimbingan kelompok.

Berdasarkan hasil pengamatan, hasil perhitungan pre-test dan post-test, juga hasil analisis wilcoxon dapat disimpulkan bahwa sampai akhir pertemuan kedelapan indikator hubungan sosial antar teman sebaya siswa tentang memiliki memiliki keterampilan sosial yang baik mengalami peningkatan.

Dari keseluruhan hasil analisis peningkatan hubungan sosial antar teman sebaya siswa diketahui bahwa melalui layanan bimbingan kelompok selama delapan kali pertemuan, dengan materi dan topik- topik tugas yang sesuai dengan tujuan yang ingin dicapai tingkat hubungan sosial antar teman sebaya pada siswa kelas VII B SMPN 1 Banyuglugur mengalami peningkatan yaitu sebesar $51,33 \%$ dalam kriteria rendah menjadi $72,67 \%$ termasuk dalam kriteria tinggi. Terjadi peningkatan sebesar 21,34\%.

Analisis wilcoxon tentang peningkatan hubungan sosial antar teman sebaya melalui layanan bimbingan kelompok pada siswa kelas VII B SMPN 1 Banyuglugur ditunjukan berdasarkan hasil uji beda dua rata-rata yaitu pada pre-test 140dan post-test yang diperoleh yaitu $Z_{\text {hitung }}=2,803$ dan $Z_{\text {tabel }}=1,96$ sehingga $Z_{\text {hitung }}>Z_{\text {tabel. }}$ Dengan demikian dapat diketahui ada perbedaan tingkat hubungan sosial antar teman sebaya siswa setelah memperoleh layanan bimbingan kelompok.Oleh karena itu, hipotesis yang menyatakan bahwa hubungan sosial antar teman sebaya dapat ditingkatkan melalui layanan bimbingan kelompok diterima. 


\section{KESIMPULAN}

Tingkat hubungan sosial antar teman sebaya siswa sebelum mendapatkan layananbimbingankelompokpada 10 siswa anggota layanan bimbingan kelompok termasuk dalam kategori rendah, yaitu dengan jumlah skor rata-rata sebesar 133 dan memiliki prosentase sebesar 51,23\% tergolong dalamkategori rendah.

Tingkat hubungan sosial antar teman sebaya siswa setelah mendapat layanan bimbingan kelompok Sesudah diberikan layanan bimbingan kelompok terjadi perubahan tingkat hubungan sosial antar teman sebaya siswa yaitu 4 siswa dalam kategori tingkat hubungan sosial antar teman sebaya tinggi dan 6 siswa dalam kategori tingkat hubungan sosial antar temanse baya sedang. Rata-rata persentasedari 10 siswa setelah diberikan layanan bimbingan kelompok yaitu sebesar 68,50\%. Masuk dalam kategori tinggi. 


\section{DAFTAR PUSTAKA}

Ali dan Asrori. 2005. Psikologi Remaja Perkembangan Peserta Didik. Jakarta: PT Bumi Aksara.

Ali, Mohamad. 1984. Penelitian Kependidikan Prosedur dan Strategi. Bandung: Angkasa

Arikunto, Suharsimi. 2006. Prosedur Penelitian Suatu Pendekatan Prakteik. Jakarta: Rineka Cipta.

Azwar, Saifuddin. 2005. Penyusunan Skala Psikologi. Yogyakarta: Pustaka Pelajar.

Dayakisni dan Hudaniah. 2009. Psikologi Sosial. Malang: UMM Press

Desmita. 2009. Psikologi Perkembangan. Bandung: PT Remaja Rosdakarya

Gerungan. 2002. Psikologi Sosial. Bandung: Refika Aditama

Gunarso, Singgih. 2007. Psikologi Perkembangan. Jakarta : Gunung Muria.

Hadi, Sutrisno. 2000. Statistik Jilid II. Yogyakarta: ANDI.

Hariyadi, Sugeng, dkk. 1995. Perkembangan Peserta didik. Semarang: IKIP Semarang Press.

Hartati, S.2004. Pembelajaran Kecerdasan Emosi Melalui Bimbingan Konseling Kelompok. Semarang: Konvensi Nasional ABKIN

Hidayati, Dwi. 2009. Kemampuan Peningkatan Berkomunikasi Antar Teman Sebaya Melalui Layanan Bimbingan Kelompok Pada Siswa Kelas VII di SMP Negeri 12 Semarang Tahun Ajaran 2008/2009. Skripsi. Semarang: Unnes

Hurluck, Elizabeth B. 1997. Psikologi Perkembangan Suatu Pendekatan Sepanjang Rentan Kehidupan. Jakarta: Erlangga

http://lmupsikologi.wordpress.com/2009/12/11/Tugas-perkembangan-remaja/. Kusuma, Rais. 2008. Keefektifan Bimbingan Kelompok Terhadap Peningkatan Kemampuan Berinteraksi Sosial pada Siswa kelas XI di SMA Negeri 2 Ungaran Tahun Ajaran 2007/2008. Skripsi. Semarang: Unnes

Mappiare, Andi. 1982. Psikologi Remaja. Surabaya: Usaha Nasioanal

Mighwar, Muhamad. 2006. Psikologi Remaja. Bandung: Pustaka Setia

Mugiarso, Heru. Dkk. 2007. Bimbingan dan Konseling. Semarang: UPT MKK UNNES Press.

Prayitno. 1995. “Layanan Bimbingan dan Konseling Kelompok (Dasar dan Profil)”. Jakarta: Ghalia Indonesia.

Prayitno dan Amti, Erman. 1994. Dasar-dasar Bimbingan dan Konseling. Jakarta: Ghalia Indonesia.

Romlah, Tatiek. 2001. Teori dan Praktek Bimbingan Kelompok. Malang: UNM 
Santrock, John W. 1983. Life - Span Develepment Perkembangan Masa Hidup. Jakarta: Erlangga

Sarwono, Sartito Wirawan. 2002. Psikologi Remaja. Jakarta: PT Grafindo Persada

Setiaji, Wahyu. 2010. Meningkatkan Kematangan Sosial Siswa Melalui Layanan Bimbingan Kelompok pada Siswa Kelas VII SMP Negeri 8 Cilacap Tahun Ajaran 200902010. Skripsi. Semarang: Unnes

Soekanto, Soerjono.1990. Sosiologi: Suatu Pengantar. Jakarta: Rajawali

Soeparwoto, dkk. 2004. Psikologi Perkembangan. Semarang: Unnes Press.

Sugiyo. 2005. Komunikasi Antar Pribadi. Semarang: Unnes Press

Sugiyono. 2005. Statistika Untuk Penelitian. Bandung: CV Alvabeta.

Sukardi, Dewa, Ketut. 2003. “Manajemen Bimbingan dan Konseling di Sekolah”. Bandung: Alfabeta.

Sulistianan. 2010. Meningkatkan Keterampilan Sosial Siswa Melalui Layanan Bimbingan Kelompok pada Siswa Kelas Viii Smp Negeri 3 Juwana Tahun Pelajaran 2009/2010. Skripsi. Semarang: Unnes

Sunarto dan Hartono. 2002. Perkembangan Peserta Didik. Jakarta: Rineka Cipta

Walgito, Bimo. 2001. Psikologi sosial. Yogyakarta: Penerbit Andi

Wibowo, Mungin Eddy. 2005. Konseling Kelompok Perkembangan. Semarang. UNNES Press

Yusuf, Syamsu. 2006. Psikologi Anak dan Remaja. Bandung: PT Remaja Rosdakarya 